\title{
Connotative Component of Lexico-semantic Units in Oral Business Communication
}

\author{
Natalya Bozhenkova \\ Doctor of Philology, Professor, Department of Theoretical and Applied Linguistics \\ South-West State University; natalyach@mail.ru
}

\begin{abstract}
Nina Romanova
Doctor of Pedagogical Sciences, The Head of Department of the Russian Language Bauman Moscow State Technical University; romanova-mgtu@yandex.ru
\end{abstract}

Irina Amelina

Lecturer, Department of Theoretical and Applied Linguistics, South-West State University Kursk, Russia; amelina.i.o@yandex.ru

Darya Atanova

Lecturer, Department of Theoretical and Applied Linguistics, South-West State University Kursk, Russia; atanova.dariya@mail.ru

Anastasia Parshina

Lecturer, Department of Theoretical and Applied Linguistics, South-West State University Kursk, Russia; snoopy-05@mail.ru

\section{Doi:10.5901/mjss.2015.v6n6s5p96}

\section{Abstract}

\begin{abstract}
Recently the expressions containing a connotative component more and more actively penetrate oral business speech, the base of which is formed by neutral lexicon, and alter greatly not only the shape and the style features of the official speech but also the organization laws of a business communication act. In this regard the need to find a new description for the ways of representing lexemes connotation determined by the importance and dynamism of the considered social area of interaction business communication - becomes obvious. The use of the lexicon possessing connotative meaning in oral business communication is not only relevant, but in some cases may also be very appropriate in order to ensure effective impact on the interlocutor and achievement of the desirable goal. The theoretical data gain special relevance in the lingvodidactic aspect as teaching Russian as a foreign language for business communication to foreign speakers with consideration of the lexicon possessing connotative meaning and therefore national and cultural specifics will contribute to building sociocultural competence in the conditions of general development of professional and communicative skills.
\end{abstract}

Keywords: connotation, emotional and expressive lexicon, professional and communicative competence, business communication.

\section{Introduction}

Business communication, being a professional communicative form of activity in production and non-production spheres, is intended for the organization of official contacts between employees in order to solve common problems and achieve desired results. Business communication's purpose is to ensure that the process of exchanging ideas, information, instructions on the internal or external levels which is a fundamental feature of all organizations, functions smoothly and effectively (ABE Diploma in Business Administration). A significant part of economic, legal and administrative information is transmitted and maintained with the help of business documentation, at the same time oral communication plays an equally important role in the establishment of the partnership, business relationships, in the organization of daily professional contacts, and the written form of business communication is carried out in accordance with the standards of the style of official documents, whereas oral business communication, implemented not only in strictly formal or official 
(not recorded business communication in a working environment), but also informal (business communication in a nonworking environment) situations, allows to make use of colloquial and bookish elements of speech which possess a strong connotative meaning.

Recently the expressions containing a connotative component more and more actively penetrate oral business speech, the base of which is formed by neutral lexicon, and alter greatly not only the shape and the style features of the official speech but also the organization laws of a business communication act. In this regard the need to find a new description for the ways of representing lexemes connotation determined by the importance and dynamism of the considered social area of interaction - business communication - becomes obvious. Such theoretical data gain special relevance in the lingvodidactic aspect as teaching Russian as a foreign language for business communication to foreign speakers with consideration of the lexicon possessing connotative meaning and therefore national and cultural specifics will contribute to building sociocultural competence in the conditions of general development of professional and communicative skills.

\section{Literature Review}

Many scientists (Ş. Cepik, E.I. Dibrova, O.I. Kourova, C.E.Osgood, G.J. Suci, P.H. Tannenbaum, L.O. Zaytseva) have dealt with the issues of identification of a connotative component of lexico-semantic units and in their works connotation is defined as an additional co-meaning containing substantive and / or stylistic (emotional, evaluative, expressive) constituents of the word meaning, that are generally accepted in the language (Dibrova, 2006, 184). The term is used to refer to the socio-cultural and 'personal' associations (ideological, emotional, etc.) of the sign that are typically related to the interpreter's class, age, gender, ethnicity and so on (Chandler, 2007, 138). To be more exact, connotation, conveying the attitude of the speaker to the signified object or phenomenon, is an emotional and evaluative component of the lexical meaning. According with the current research in the field of psychology, psycho- and sociolinguistics and other disciplines, "emotive function of the language manifests itself in various aspects and emotions permeate all aspects of human existence, all levels of the language, concluding special lingvocultural meanings" (Dinevich, Konshina 2013, p. 7): pustjakovoe delo (child's play), zarjadit' cenu (to boost the price), uhodit s koles (sells out immediately), etc. (All the examples here and henceforth are given in Russian with their translation into English. However, the English variant sometimes, unfortunately, loses the necessary connotative component.)

Describing connotation as a linguistic phenomenon some scientists speak about connotation components while the others characterize various types of connotations. Thus L.O. Zaytseva systematizing research data on the structure of connotation points out that four elements can be sorted out in the specified structure - emotive (emotional), evaluative, expressive and stylistic (Zaytseva, 2014, p. 532). Şaban Cepik mentions that there are at least three types of connotation mentioned in linguistic literature: evaluative, power-solidarity and associative (metaphor) (Cepik, 2006, 144). O.I. Kourova, summarizing the researchers' points of view on the matter, comes to conclusion that scientists single out various types of connotations: emotional, evaluative, figurative and expressive; descriptive, intensive, evaluative, emotive. At the same time the author mentions that some authors dwell on the classification of connotation components and nominate emotional and evaluative, parametrical (includes intensity component), stylistic and cultural (these types of connotation components can be combined) constituents of connotation (Kourova, 2006, p. 69). What's more, some scientists speak about emotional connotation as a general term and its three underlying dimensions: Evaluation, Potency and Activity (Osgood, Suci \& Tannenbaum, 1957, p. 50).

It should be noted that the differences in the metalanguage, the researchers use to describe connotation, don't disprove that the essence of the phenomenon is considered from the same side. In the conditions when a full agreement in the issue of connotation analysis hasn't been achieved yet each scientist as it is visible from the given classifications, adheres to his own terminology, however such specification isn't obligatory within oral business communication therefore, in accordance with E.I. Dibrova, we will speak about emotional, evaluative and expressive connotations (Dibrova, 2006, p. 188). Emotional connotation is connected with the expression of feelings, strong-willed motives, sensory or intellectual comparisons (domishko - little house, spravochka - certificate). Evaluative connotation establishes the value or the meaning of someone / something through approval or disapproval. It may carry connotation ranging from 'pleasant' to 'unpleasant' (Vacoch, Wurm, 1997, p. 341). Positive evaluation is passed through a positive emotion: affection, praise, admiration, approval, etc. (ptichka - birdie, molodec - good fellow). Negative evaluation is connected with negative emotions: condemnation, rejection, disapproval, contempt, irony, etc. (komnatenka - cubby, gerojstvovat' - display heroism). Expressive connotation suggests presenting information, "recycled" in the inner world of a person and bearing expressiveness of his perception of the world - zaoblachnyj (transcendental), izjuminka (zest).

At the same time, according to the fair remark of L.O. Zaytseva, in many cases it is difficult to differentiate between 
evaluative and emotional components: emotional connotation implicitly gives evaluation due to the fact that "the existence of additional emotive features in semantics of the word presupposes that the process of nominating an object that receives a name, is assessed in terms of what emotions it can cause, what emotional impressions it can steadily be associated with" (Zaytseva, 2014, p. 532). Thus, it is possible to talk about integral emotional (emotive) and evaluative connotation.

In oral business communication a pronounced connotative component is contained in the semantic structure of emotionally coloured vocabulary, which may be regarded as a special category of the lexical structure of the language. It is usually high flown words (otnyne (henceforth), prednachertanye (predestination), vozdvignut' (erect), vsepobezhdajushhij (all-conquering)) or substandard, familiar vocabulary (pichuga (birdie), orat' (yell), revet' (howl), vzbuchka (scolding)) that have emotional and evaluative, expressive connotations. However, neutral words can become expressive as well in accordance with the context. This statement can also be applied to the terms: Ja znaju kompaniju do molekul! (I know the company to bits (molecules)!)

D.E. Rosenthal includes three groups of words in the structure of emotional and expressive lexicon:

1) words with a pronounced connotative meaning that are usually unambiguous, contain assessment of the facts, phenomena, features, give monosemantic assessment of people: voodushevit' (to inspire), voshititel'nyj (delightful), derzanie (aspiration), neprevzojdennyj (unsurpassed), brjuzga (grumbler), dopotopnyj (antediluvian), napakostit' (to play a dirty trick), podhalim (the bootlicker), pustozvon (gas-bag), razgil'djaj (sloven);

2) polysemantic words, neutral in the basic meaning, that acquire qualitative and emotional nuance when used in a figurative sense: trjapka (rag), tjufjak (lump), dub (blockhead), vorona (gaper), popugaj (parrot) (as a characteristic of a person);

3) words with suffixes of subjective evaluation, conveying various shades of feeling: synochek (sonny), dochurka (daughter), solnyshko (sunny), akkuratnen'ko (neatly) - positive emotions; detina (big fellow), kazenshhina (bureaucratic approach) - negative emotions (Rosenthal, 2010, p. 100).

Phraseological units can be undoubtedly considered as emotional and expressive lexicon in view of the fact that the set of words in their structure can be reduced to one word and render an integral meaning. The use of idioms is calculated on creating an image in the consciousness of the interlocutor and by that on the appeal to his emotional sphere. Besides they possess vivid national and cultural colouring and that is especially important when using the research data in the course of teaching Russian as a foreign language to form sociolinguistic and sociocultural competence as components of the overall professional communicative competence of students. By the way, it is exactly cultural connotations of the words that are stated among three main areas (others are conventional behavior in common situations and the ways language and social variables interact) that can help to improve communicative competence (Csajbok-Twerefou, 2010, p. 208). Teaching Russian as a foreign language is conducted in a language foreign to the students, their training is carried out in a new sociocultural and ethnic environment. In this regard, the educational role of the language as a cultural phenomenon, which makes it possible for foreigners to understand Russian national system of values, improve social competence and adapt their communication strategies to interact with representatives of various ethnic and cultural groups, is constantly increasing.

\section{Purpose, Materials and Methodology}

In this paper we concentrate on the use of lexico-semantic units with connotative component in oral business communication and analyze their role in this process. Understanding of the ways to apply such verbal means of the language in business conversation contributes to the development of professional communicative competence of the students of economic specialties: this knowledge helps them to avoid discrepancies in communication between the participants of the communicative act that due to inadequate perception of information may result in negative consequences like terminating all the business relationships between the partners.

Since we plan to employ the findings of our work in teaching the methods of business communication to students within the course "Russian as a foreign language" in the first years of undergraduate (bachelor / specialist) programme $\left(1^{\text {st }}-2^{\text {nd }}\right.$ years) the fragments of Soviet and Russian movies and TV series ("Luck Is More Important", "Office Romance", "Office Romance. Our Time", "Daddy for Sofia", "Peter The Perfect "," All for You"," Next-2 ","The Three Semi-Graces") were chosen as the materials for our research being among the most effective teaching aids.

The study uses observational research method aimed to identify the lexicon possessing connotative meaning in the oral business communication and determine its function. 


\section{Connotations within Oral Business Communication}

Verbal communication in the field of business can't be divided from the emotional sphere of the people involved in the conversation and we can state that all the groups of emotional and expressive lexicon are represented in modern oral business communication. This type of communication is always focused on the result, the impact on the interlocutor, achievement of a certain purpose therefore the choice of lexical means to express the content of the speech is an important part in its organization.

Without any doubt, conventional norms of businessmen's speech etiquette set certain limits on the use of verbal means of the language but, anyhow, the oral form of business communication owing to such characteristics as spontaneity to some extent, as well as simplified nature in the construction of the statements to ensure the availability of information, allows involvement of colloquial and bookish phrases that in most cases possess emotive, evaluative, expressive components, this usage does not prevent, but on the contrary contributes to obtaining the desired result of the conversation, to solving some existing problems.

Analyzing the role of the lexicon possessing connotative meaning in the oral business communication we may single out its following functions:

1) contact establishment;

2) influence for the purpose of persuasion (with possible displaying of the status);

3) influence for the purpose of receiving reaction.

To identify and illustrate these functions of the lexicon possessing connotative meaning in oral business communication we will employ the materials of Soviet and Russian movies and TV series stated above. It should be noted that all groups of emotional and expressive lexicon are presented in the chosen video fragments:

1) words with a pronounced connotative meaning: golubushka (my dear), unichtozhit' (to destroy), kapriznichat' (to be capricious);

2) polysemantic words, neutral in the basic meaning, that acquire qualitative and emotional nuance when used in a figurative sense: molodaja porosl' (young growth), trjapka (rag), hromat' (limp), horonit' (bury), prosochit'sja (leak), smyvat' (flush);

3) words with suffixes of subjective evaluation, conveying various shades of feeling: spravochka (certificate);

4) phraseological units: sluzhit' veroj i pravdoj (to serve with good faith and fidelity), rabotat' kak loshad' (to work like a horse), okazat'sja u razbitogo koryta (be no better off than before), kto $v$ dome hozjain (who wears the breeches), proshu ljubit' i zhalovat' (please make him/ her feel welcome), nabivat' sebe cenu (play hard to get), sgushhat' kraski (lay it on thick), bumaga ne krasneet (paper doesn't blush).

The function of contact establishment provides a necessary atmosphere for conversation, is aimed to win your partners favour, get him to be friendly with you, prepare him for the future collaboration and often finds reflection in addressing a person:

- O, nasha molodaja porosl', Varvara Kulikova. Kak nastroenie? («Papa dlja Sofii»)

- Oh, our young growth, Varvara Kulikova. How do you feel? ("Daddy for Sophia")

- Oj, Kulikova, kakaja ty vsjo-taki ne pozitivnaja! Ja ne rugat' tebja priglasil, a naoborot... Zagranpasport u tebja est'? ("Papa dlja Sofii»)

- Oh, Kulikova, how pessimistic you are! I don't want to scold you, it's vice versa ... Do you have an international passport? ("Daddy for Sophia")

- Olesja Vitol'evna, rad Vas videt', prohodite, sadites', golubushka. Kak dela? («Tri polugracii»)

- Olesya Vitolyevna, I am glad you to see, come in, sit down, my dear. How are you? ("Three Semi-Graces")

The function of influence for the purpose of persuasion is activated when the speaker uses emotional and expressive lexicon to state his point of view, describe a certain state of affairs and wants his interlocutor to agree with him, hold the same opinion. This function may add display of the status to the purpose of persuasion which manifests itself in pointing out the superiority - intellectual, social, etc .:

- I pochemu prekratili sotrudnichestvo s predydushhim partnjorom? Naskol'ko ja ponimaju, on sluzhil nam veroj i pravdoj. Tri s polovinoj goda, i uslovija byli ochen' vygodnymi. («Petja Velikolepnyj»).

- Why did we stop to cooperate with the previous partner? As far as I understand, it served us with good faith and

fidelity. For three and a half years, and the conditions were very favorable. ("Peter The Perfect")

- Ja hochu, chtoby Vy podgotovili prezentaciju nashego agentstva.

- Prezentacii - jeto moj konek. («Sluzhebnyj roman. Nashe vremja»)

- I want you to prepare a presentation of our agency. 
- Presentations are my strong point. ("Office Romance. Our Time")

- I, tem ne menee, ja uveren, chto jetot tvoj genial'nyj plan dovedjot nashu firmu do razbitogo koryta. («Ne rodis' krasivoj»)

- And nevertheless I am sure that with this brilliant plan of yours our company will be no better off than before. ("Luck Is More Important")

- Da, i po povodu arhitekturnogo reshenija, chestno govorja, ja zhdal ot vas bol'shego. Ja tozhe umeju kapriznichat'. ("Vsjo radi tebja»)

- Oh, and about the architectural solutions, to be honest, I expected more of you. I can be capricious as well. ("All for You")

When the function of influence for the purpose of receiving reaction is carried out, unlike the function of influence for the purpose of persuasion, the choice of emotional and expressive lexicon is directed on regulating interlocutor's behavior, getting results in the form of any activity:

- Znachit, ja Vas kak svoego zamestitelja proshu obratit' osoboe vnimanie na disciplinu. Disciplina, $k$ sozhaleniju, u nas hromaet. ("Sluzhebnyj roman»)

- So, I ask you as my deputy to pay special attention to the discipline. Discipline, unfortunately, leaves much to be desired. ("Office Romance")

- Ne nado konkretizirovat', ty luchshe zvoni svoemu brokeru, puskaj konchaet smyvat' imperiju po kusochkam. («Nekst2»)

- Don't concretize, you'd better call your broker and make him stop flushing the empire down the drain. ("Next-2")

- Pishite, pishite, pishite, pishite! Bumaga ne krasneet! Pishite! ("Sluzhebnyj roman»)

- Please, do write! Paper does not blush! Write now, will you? ("Office Romance")

\section{Conclusion}

Thus, the use of the lexicon possessing connotative meaning in oral business communication is not only relevant, but in some cases may also be very appropriate in order to ensure effective impact on the interlocutor and achievement of the desirable goal. Thematically topical materials applied for teaching foreign languages in the system of higher professional education intensify development of professional and communicative competence of a future specialist (Romanova \& Amelina, 2015, 29), formation of professional language personality of an expert capable to solve constructively problems of intercultural business interaction. They reflect the characteristics of lingvocommunication in a particular social sphere, as well as motivate to a deeper comprehension of the cultural specifics of Russian lingvosociety that makes it easier and faster to adapt to new sociocultural conditions. Thanks to such 'immersion' into the realities of a foreign language environment, which is supported by the visual and audial reception, as well as emotional and evaluative perception, multicultural competence of a specialist is formed and that is extremely important for ensuring effective professional and business interaction between the representatives of different lingvosocieties and strengthening integration processes of the modern world.

\section{References}

ABE Diploma in Business Administration. Study Manual. Business communication. [Online] Available: http://www.pc-freak.net linternational_university_college_files/Business\%20Communication.pdf (Not dated)

Cepik, Ş (2006) Positive Neutral Negative evaluation in connotation. IBSU International Refereed Multi-diciplinary Scientific Journal, 1 , $144-147$.

Chandler, D. (2007) Semiotics: The Basics. (2nd ed.). London and New York: Routledge. Taylor \& Francis Group.

Csajbok-Twerefou, I. (2010) Language Etiquette and Culture in Teaching of Foreign Languages. Practice and Theory in Systems of Education, Vol. 5, $205-218$.

Dibrova, E.I., Ed. (2006) Sovremennyj russkij jazyk: Teorija. Analiz jazykovyh edinic [Modern Russian: Theory. The analysis of language units]. Part 1. Moskva: «Akademija».

Dinevich, I.A., Konshina, E.E. (2013). Ob osobennostjah upotreblenija jemotivnyh edinic v russkom i anglijskom jazykah [Peculiarities of the use of emotive words in the Russian and the English languages]. Izvestija JuZGU. Serija: Lingvistika i pedagogika, 1, 7-12.

Kourova, O.I. (2006) Konnotacija kak sposob hranenija kul'turnoj informacii [Connotation as a way to store cultural information]. Vestnik Severnogo (Arkticheskogo) federal'nogo universiteta. Serija: Gumanitarnye i social'nye nauki, 1, 68 - 73.

Osgood, C.E., Suci, G.J. \& Tannenbaum, P.H.(1957) The measurement of meaning. Urbana, IL: University of Illinois Press.

Romanova, N.N., Amelina, I.O. (2015) Opyt obuchenija studentov-jekonomistov delovoj kommunikacii v processe prepodavanija RKI s audiovizual'nym soprovozhdeniem [The experience of teaching business communication to students of economic specialties within the course of Russian as a foreign language with the help of audiovisual aids]. Materiali za 11-a mezhdunarodna nauchna praktichna konferencija, «Novini na nauchnija progres». Tom 4. Pedagogicheski nauki. Fizicheska kultura i sport. Sofia: «Bjal Grad-BG» OOD. 22 - 30. 
Rosenthal, D.E., Golub, I.B., \& Telenkova, M.A. (2010) Sovremennyj russkij jazyk [Modern Russian]. Moskva: Ajris-Press.

Vacoch, D.A., Wurm, L.H. (1997) Emotional connotation in Speech Perception: Semantic Associations in the General Lexicon. Cognition and Emotion, 11 (4), 337 - 349.

Zaytseva, L.O. (2014) Osobennosti konnotativnogo komponenta znachenija leksicheskih edinic v zhurnalah 0 «Kino» [Features of a Connotative Component of the Word Meaning in the Magazines about "Cinema"]. Molodoj uchenyj, 10, 531-534. 